\title{
Selecting a topic for research in general medicine
}

\author{
Jose Luis Turabian* \\ Specialist in Family and Community Medicine, Health Center Santa Maria de Benquerencia. Regional Health Service of Castilla la Mancha (SESCAM), Toledo, Spain
}

\section{Editorial}

If the different existing research manuals are analyzed, the wide variety of opinions on the meaning of the research process is appreciated, as well as the notable differences between the projects or designs presented. However, all these diverse research perspectives share certain common characteristics: they start from assuming the research process in a planned, strategic, systematic and reliable way to deepen knowledge and, therefore, the common denominator is constituted by three axes or points fundamentals: 1 . The subject to investigate; 2 . The problem to solve; 3 . The methodology to be used. Of course, they are interrelated, and one of them can not solve without decrying the others. But, in any case, the subject could be the first big decision that the researcher must take [1,2], although, surely only after you can decide the method that best suits to you, the particular purpose of the study can be chosen [3].

The investigations originate in ideas that man makes, related to a given situation in a fact, process or phenomenon of nature, society or thought. These ideas constitute, therefore, the first approach to the object of reality that will be investigated. It's about being open-eyed and maybe making a "list of research ideas" [4].

The "investigation momentum" [5] may appear unexpectedly. You should look for inspiration - the idea, the "hunch" - in nature and in daily work, from practice: it is like saying, starting from observation, which gives us the surprise, excitement and emotion, which are propelling forces of constructive imagination. That is, to practicing curiosity [6,7].

Many phenomena can easily pass unnoticed, however obvious they may be, before anyone has studied them. A good idea may be to begin to group data to extract laws or general conclusions from them. Darwin said: "When one begins to examine an unknown territory, nothing seems more hopeless than the chaos of the rocks; but as the stratification and the nature of those and the fossils are recorded in multiple points, always speculating and forecasting what we will find in other places, the region becomes clear, and its overall structure becomes more or less intelligible" [8].

Thus, the reflective researcher, from his daily practice, must be able to obtain "experience from experience". There is a type of experience that refers to a kind of experimental method of trial and error, which allows us to learn, and that probably there is no way to replace it in medical training and research. The practice of medicine is still a continuous process of development and self-correction. It is a living experience: diverse sources provide us with ideas and pose problems that may raise questions in those of us who are practicing the clinic. In the reading of certain texts, when treating patients, when we talk about clinical cases ..., we can find -we can see with some ease- areas of superposition of problems. It seems that it is our patients, with their strange problems "that force us to think about the basic problems [9].
And this leads us to a reflection-action cycle: moving in this cycle - from concrete experience, to reflection and analysis of experience, to the identification of theoretical frameworks that explain experience, and finally to its application through active experimentation - the new learnings are integrated and, as a result, knowledge, skills and attitudes are consolidated, developed and refined over time. Failure to complete the cycle leads to a total or partial loss of learning opportunities [10].

Being reflexive does not give us definite answers to problems but highlights the need to engage in critical questioning and deeper debate about taken-for-granted issues that have potential moral and ethical implications [11].

We must be in search of a new fact. This is often the fruit of patient and tenacious observation; of the experience on the chosen subject that ends up endowing us with a refined analytical sensitivity and as over-excited. This allows the researcher, at a glance, to see entirely new things that others do not see. But there is also a part of chance that is guided by intuition and knowledge. This "serendipity", that is, the gift of finding valuable things not sought, or the ability to make lucky and unexpected discoveries by accident, this chance, does not smile to the one who wants it, but "to the one who deserves it", or as Pasteur said "chance favors only the prepared mind" ("Chance exists, but it has to catch us working", said also the painter Picasso). In science, as in the lottery, luck favours the one who plays the most, that is, fortunate chance is usually the reward of persevering effort $[12,13]$.

Another useful suggestion was also given to us by Darwin: "For many years I have also followed a golden rule, namely that whenever I came across a published piece of information, a new observation or idea that was opposite to my general results, I wrote it down quickly and without fail, as I had realized from experience that such data and ideas were more likely to escape quickly from memory than favourable ones" [8].

It can be a good rule, about how decide on the subject of research, to follow our first thoughts, and not the second ones: "When there is not time for real deliberation, it is generally safer to act on our first thoughts than on our second. For the first thoughts are likely to turn on the greater probabilities and more important points of the case; the second on some minor matter which qualifies and limits the former" [14].

Other good suggestions to think about the subject are: to start from the problems that have been pending solution, from the future suggested lines of research of previous studies; when we find ourselves

${ }^{\star}$ Correspondence to: Turbain JL, Health Center Santa Maria de Benquerencia Toledo, Spain, E-mail: jturabianf@hotmail.com

Received: September 21, 2018; Accepted: September 26, 2018; Published: September 28, 2018 
in the presence of several equally favorable and fruitful topics, choose one whose methodology is perfectly known to us and for which we feel more sympathy. If, with the subject or problem does not feel your enthusiasm grow or increase your strength, you must abandon this scientific enterprise. On the other hand, let's not be megalomaniacs. We must be humble from the beginning; First, tackle small issues, to tackle later, if success smiles and forces grow, the big ones [4].

Recall that, conquered the first new fact, the task of researcher will be as easy as brilliant: it will be only to go progressively removing the consequences of this new fact. The first discovery is the one that costs, the others tend to be corollaries of the first. Every problem solved raises an infinity of new questions. And so, it is better to risk repeating "discoveries", that not to do any attempt at experimental inquiry; even the beginner researcher, who in his first essays knows that there is things published a short time before about its reseach, can fortify his confidence in his own worth, and so he takes courage for future enterprises, and ends up producing original science.

\section{References}

1. Zapata O (2005) Como encontrar a tema to build a tema of investigation? Innovación Educativa 29: 37-45.

2. Bell J (1997) Doing your research project. A guide for first-time researches in education and social sciences, Buckingham: Open University Press.
3. Turabian JL (2018) Looking for the best journey: Real methodology of research in general medicine. International Journal of General Practice 1: 1-7.

4. Ramón y Cajal S (1944) The tonics of the will. Buenos Aires: Austral. Espasa-Calpe Argentina.

5. Sah S, Elias P, Ariely D (2013) Investigation Momentum: The Relentless Pursuit to Resolve Uncertainty. JAMA Intern Med 173: 932-933.

6. Winner J (2017) Reducing Frustration and Increasing Fulfillment: Mindfulness. Fam Pract Manag 24: 28-32.

7. Turabian JL, Perez Franco B (2003) Irrelevant research in primary care? Is clinical research used to generate evidence from practice? Aten Primaria 32: 259.

8. https://www.libros-antiguos-alcana.com/charles-darwin/autobiografia/libro

9. Rogers C (1995) A way of being. New York: Houghton Mifflin Company.

10. Turabian JL, Pérez Franco B (2008) Map Towards Adventure. Aten Primaria 40: 209216

11. Cunliffe AL (2016) "On Becoming a Critically Reflexive Practitioner" Redux: What Does It Mean to Be Reflexive? Journal of Management Education 40: 740-746.

12. Roberts RM (1989) Serendipity. Accidental Discoveries in Science. New York: John Wiley \& Sons, Inc.

13. Burke J (1996) The Pinball Effect. London: Writers Ltd.

14. http://oll.libertyfund.org/titles/mill-collected-works-of-john-stuart-mill-in-33-vols

Copyright: $@ 2018$ Turabian JL. This is an open-access article distributed under the terms of the Creative Commons Attribution License, which permits unrestricted use, distribution, and reproduction in any medium, provided the original author and source are credited. 